\title{
JUURNAL.RU
}

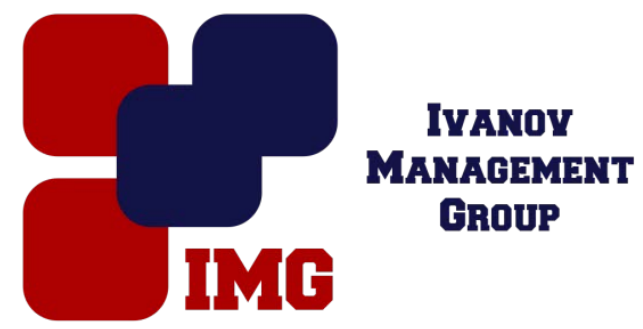

\author{
Дубова А.В., Чумакова О.О. \\ Чувашский государственный университет им. И.Н. Ульянова \\ Чебоксары, Россия
}

doi: 10.18411/lj-28-02-2017-3-01

idsp 000001:lj-28-02-2017-3-01

\section{Анализ частоты и характера патологических ортостатических реакций при сердечно-сосудистых заболеваниях}

\section{Аннотация.}

В статье анализируется частота встречаемости патологических ортостатических реакций у пациентов, страдающих сердечно-сосудистыми заболевания. Установлена взаимосвязь типов патологических ортостатических реакций с выраженностью прогрессирования основного заболевания, наличием сопутствующей патологии.

Ключевые слова: ортостатические реакции, патологические ортостатические реакции, сердечно-сосудистые заболевания.

Введение. В физиологических условиях переход из горизонтального положения в вертикальное (ортостаз) приводит к снижению центрального объема кровотока приблизительно на 20\%. Артериальное давление (АД) при этом уменьшается, что является мощным раздражителем для кардиопульмональных, аортальных, каротидных механорецепторов [1] и приводит к увеличению ударного объема левого желудочка, повышению периферического сосудистого сопротивления, восстановлению венозного возврата и адекватной перфузии органов. В норме стабилизация ортостаза наступает в течение 60 секунд и менее [2].

Данные многочисленных исследований (INVEST, ACCORD- BP, ABCD) свидетельствуют, что ортостатические реакции (OP) артериального давления (АД) и частоты сердечных сокращений (ЧСС) оказывают значительное влияние на течение и прогноз сердечно-сосудистых заболеваний (СС3). Гипотензивные ОР (снижение систолического артериального давления (САД) на 20 и более мм. рт. ст. и/или диастолического артериального давления (ДАД) на 10 и более мм. рт. ст. от исходного в течение 3-х минут после перехода в ортостаз [3]) повышают риск развития неблагоприятных кардиоваскулярных событий и смертности [4]. Гипертензивные ОР АД связаны с высоким риском развития «немых» инсультов у пациентов с артериальной гипертензией (АГ) [5]. Вышеперечисленные данные обусловливают актуальность изучения частоты и характера ортостатических 
реакций среди пациентов, страдающих ССЗ. Целью нашего исследования стало изучить распространенность, характер и направленность патологических ортостатических реакций среди пациентов с кардиальной патологией.

Материалы и методы. Обследовано 62 пациента (25 мужчин и 37 женщин), находящихся на круглосуточном стационарном лечении в кардиологическом отделении БУ «ГКБ №1» г. Чебоксары. Средний возраст $62 \pm 11,4$ лет.

Рутинное обследование пациентов включало общеклинические и биохимические анализы крови, суточное мониторирование АД и электрокардиограммы (ЭКГ), эхокардиоскопию (ЭхоКС), определение скорости клубочковой фильтрации (СКФ) по Кокрофту-Голду.

Для выявления предрасположенности у пациентов к развитию ОГ нами использовалась активная ортостатическая проба (АОП), как наиболее простая и высокоинформативная методика функционального исследования сердечнососудистой и вегетативной нервной системы.

На основании полученных результатов выделены следующие группы пациентов с ортостатическими патологическими изменениями: 1) ортостатическая систолическая гипотония - снижение САД на 20 и более мм. рт. ст.; 2) ортостатическая диастолическая гипотония - снижение ДАД на 10 и более мм. рт. ст.; 3) ортостатическая диастолическая гипертония - диастолическое АД менее 90 мм. рт. ст. в положении лежа и более 90 мм рт. ст. в положении стоя; 4) ортостатическая тахикардия - увеличение ЧСС более, чем на 27 уд./мин. или более 108 уд./мин.[6]. 5) ортостатическая систолическая гипертония - повышения систолического артериального давления на 10 и более мм. рт. ст.

Результаты. Патологические ОР (ПОР) зарегистрированы у 53\% пациентов. В структуре выявленных изменений преобладают ортостатическая систолическая гипотония - 39,3\% и ортостатическая диастолическая гипертония - 36,4\%. Ортостатическая систолическая гипертония наблюдалась у 12,1\% больных, ортостатическая диастолическая гипотония и ортостатическая тахикардия в $6,06 \%$ случаев.

Согласно нашим данным ПОР у мужчин (60\%) встречались несколько чаще, чем у женщин $(48,6 \%)$, при этом у женщин преобладала ортостатическая диастолическая гипертоническая реакция $(20 \%$ мужчин, $5,6 \%$ женщин, $\mathrm{p}<0,05)$.

Возрастные различия в частоте и характере ПОР характеризуются преобладанием систолических гипотензивных реакций среди лиц старше 70 лет $(66,7 \%)$ по сравнению с более младшими возрастными группами (32\% среди лиц в возрасте 50-69 лет, $\mathrm{p}<0,05)$, для которых более характерны систолическая гипертензия (16\% в возрасте 50-69 лет, 0\% старше 70 лет, $\mathrm{p}<0,05)$.

При наличии фибрилляции предсердий (ФП) частота ПОР выше $(81,8$ \%), чем у лиц с синусовым ритмом (CР) $(41,2 \%, \mathrm{p}<0,001)$. В структуре ПОР у больных ФП преобладают систолические гипотонические реакции $(77,8 \%$ - у больных с ФП,19\% у больных с СР, $\mathrm{p}<0,001)$ и реже встречаются систолические и диастолические гипертонические реакции $(11,1 \%$ - у больных с ФП, $61,9 \%$ у больных с $\mathrm{CP}, \mathrm{p}<0,05)$. Полученные данные, вероятно, можно объяснить изменениями гемодинамики у пациентов с ФП: из-за отсутствия эффективной систолы левого предсердия при фибрилляции предсердий не происходит 
необходимое для адекватного ортостаза увеличение наполнения левого желудочка.

У пациентов с хронической сердечной недостаточностью (XCH) III-IV функционального класса (ФК) чаще регистрировались систолические гипотонические реакции по сравнению с пациентами с I-II ФК ХСН (71,4\% против $25,0 \%, \mathrm{p}<0,05)$.

Для больных с наличием сопутствующих заболеваний щитовидной железы (ЩЖ) также более характерны систолические гипотонические реакции $(61,5 \%$ у пациентов с заболеваниям ЩЖ, 25\% без патологии ЩЖ, $\mathrm{p}<0,05)$. При анализе влияний на частоту встречаемости ПОР наличия сахарного диабета, хронической болезни почек достоверных различий нами не выявлено.

Выводы. Таким образом, полученные данные о высокой распространенности ПОР среди кардиологических больных, а также увеличение выраженности систолических гипотонических реакций при прогрессировании тяжести ССЗ, говорят о необходимости более тщательного обследования и взвешенного назначения лекарственной терапии в связи с отрицательным прогностическим значением данных реакций.

\section{Литература}

1. Белова Е. Л. Адаптация к условиям ортостатической пробы у юных спортсменов в зависимости от особенностей тренировочного процесса / Е. Л. Белова, Н. В. Румянцева // Ученые записки университета имени П. Ф. Лесгафта. - 2008. - № 3 (37). - С. 21-24.

2. Lamarre-'Cliche M. The fainting patient: value of the head-upright tilt-table test in adult patients with orthostatic-intolerance/ Maxime Lamarre-Cliche, Jean Cusson // CMAJ/ -2001 N 164. -P. 372-376

3. Consensus statement on the definition of orthost atic hypotension, pure autonomic failure, and multiple system atrophy / I.J. Schatz, R. Bannister, R. Freeman [et al.] // Neurology. 1996. - Vol. 46, № 5. - P. 1470.

4. Systolic and diastolic component of orthostatic hypotension and cardiovascular events in hypertensive patients: the Captopril Prevention Project. / A. Fedorowski, B. Wahlstrand, T. Hedner [et al.1 // J. Hypertens. - 2014. - Vol. 32. - P. 75- 81

5. Гарькавий П. А., Егорова А. Ю., Яблучанський М. І. Типи ортостатичних реакцій і показники діастолічного артеріального тиску в пацентів 3 артеріальною гіпертензіею // Вісн. ХНУ ім. В. Н. Каразіна.— 2006.— № 738.- С. 75-79.

6. Моисеев, В.С. АРГУС. Артериальная гипертония у лиц старших возрастных групп/ В.С. Моисеев, Ж.Д. Кобалава - М. ООО «Медицинское информационное агенство», 2002. $-448 \mathrm{c}$. 